\title{
SISTEM APLIKASI PENGELOLAHAN DATA KOMPLAIN UNTUK MENGUKUR KUALITAS KINERJA UNIT PDE BERBASIS WEB DI RSUD BANGIL
}

\author{
Teguh Pradana ${ }^{1)}$, Anggit Septa Yurika ${ }^{2)}$ \\ Program Studi/Prodi TeknikInformatika, STMIK Yadika \\ Jl. Bader No. 09 KalirejoBangilPasuruan Indonesia, 67153 \\ Email:Inti_persada_software@yahoo.co.id ${ }^{1)}$, anggit@mhs.stmik-yadika.ac.id ${ }^{2}$
}

\begin{abstract}
Decision Support Systems (DSS) are interactive computer-based system, which helps decisionmakers to use the data and models to solve unstructured problems. Decisions can be taken by right (time and objective) and can be accounted for if it is supported by a system without doing individual aspects of the decision itself as well as the context of the problems faced.Thus the authors will take advantage of the application system pengelolahan complaint of data to measure performance web-based EDI unit. This system which will bridge the gap between students and the concentration of the majors to be taken with the help of the head of the study program. Decision Support System for Determination of Concentration Programs are designed using the programming language PHP and Mysql data base. And system design using CMS as decision support in determining the concentration of the majors to be taken in studying at the Faculty of Economics, University of the Free Pasuruan. Students are no longer confused I scared wrong in taking decisions for determination majors is to be retrieved.
\end{abstract}

Keyword:PHP,Mysql, Decision Support Systems

\section{PENDAHULUAN}

Dengan perkembangan teknologi informasi yang ada saat ini dapat melakukan pengolahan data dengan mudah, dapat menghasilkan suatu informasi yang dibutuhkan dengan akurat dan efisiensi waktu. Keunggulan inilah yang menjadikan teknologi informasi saat ini banyak berperan serta dalam segala bidang dan aspek kehidupan yang ada, dan berkembang sesuai dengan kebutuhan masyarakat.

Dari penjelasan uraian di atas, pengolahan data yang dilakukan secara manual sudah dihilangkan dan dirubah menjadi system terkomputerisasi untuk memuudahkan proses pengolahan data dan pembuatan laporan terfilter bisa dilakukan dengan cepat sehingga tidak membutuhkan waktu yang cukup lama. Dalam pengolahan data komplain di RSUD Bangil belum ada sistem terkomputerisasinya dan masih dicatat manual mengunakan notepad di komputer. Oleh karena itu, maka dibuat suatu aplikasi berbasis web yang menangani data komplain di RSUD Bangil. Tujuan dari pembuatan Aplikasi Pengelolahan Data Komplain Berbasis Web di RSUD Bangil sebagai berikut: Aplikasi
Pengelolahan Data Komplain Berbasis Web memberikan kemudahan pengolahaan data complain di RSUD Bangil. Menghasilkan Aplikasi Pengelolahan Data Komplain Berbasis Web yang dapat diterapkan di RSUD BANGIL sehingga dapat membantu mahasiswa untuk mengembangkan kemampuan terutama di bidang teknologi.

\section{METODEPENELITIAN}

Metode waterfall adalah metode yang pekerjaan-pekerjaanya mengikuti suatu pola tertentu dan dilaksanakan dengan cara dari atas kebawah. Metode ini mempunyai tahapan seperti berikut. Analisis kebutuhan, Desain sistem, Penulisan kode program, Penerapan program dan pemeliharaan. Proses di lakukan secara berututan dari proses analisis hingga penerapan program. Gambar 1 menunjukkan proses metode waterfall. 


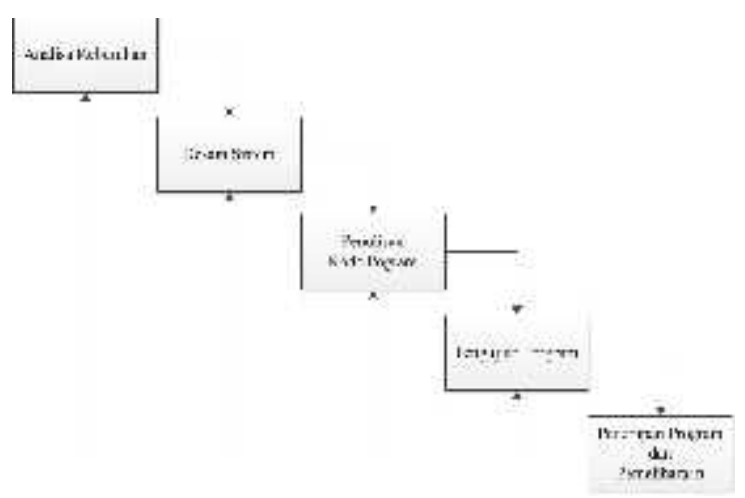

Gambar 1. Metode Waterfall

\section{Analitycal Hierarchy Process (AHP)}

AHP merupakan suatu model pendukung keputusan yang dikembangkanoleh Thomas L. Saaty. Model pendukung keputusan ini akan menguraikan masalah multi factor atau multi kriteria yang kompleks menjadi suatu hirarki, menurut Saaty (1993), hirarki didefinisikan sebagai suatu representasi dari sebuah permasalahan yang kompleks dalam suatu struktur multi level di mana level pertama adalah tujuan, yang diikuti level faktor, kriteria, sub kriteria, dan seterusnya ke bawah hingga level terakhir dari alternatif. Dengan hirarki, suatu masalah yang kompleks dapat diuraikan ke dalam kelompok-kelompoknya yang kemudian diatur menjadi suatu bentuk hirarki sehingga permasalahan akan tampak lebih terstruktur dan sistematis. AHP sering digunakan sebagai metode pemecahan masalah disbanding dengan metode yang lain karena alasan-alasan sebagai berikut:

1. Struktur yang berhirarki, sebagai konsekuesi dari kriteria yang dipilih, sampai pada subkriteria yang paling dalam.

2. Memperhitungkan validitas sampai dengan batas toleransi inkonsistensi berbagai criteria dan alternatif yang dipilih oleh pengambil keputusan.

3. Memperhitungkan daya tahan output analisis sensitivitas pengambilan keputusan

Diagram konteks merupakan diagram yang digunakan untuk mengidentifikasi entitas luar yang terhubung langsung dengan sistem.

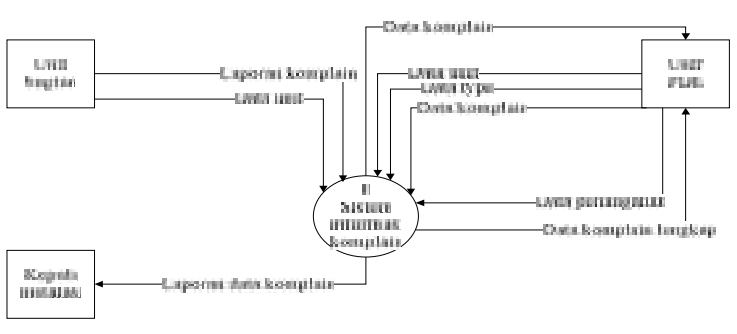

Gambar 2. Diagram konteksSistem

Context Diagram pada system komplain di ruang PDE RSUD Bangil terdiri dari 3 external entity yaitu Unit bagian, User PDE serta Kepala instalasi. External entity tersebut memberikan suatu informasi kepada sistem yang terlihat pada gambar 2 .

DFD Level 0 merupakan gambaran lebih rinci dari diagram konteks pada sistem. DFD Level 0 pada system komplain di ruang PDE RSUD Bangil mempunyai 5 proses utama yaitu penerimaan komplain, pendataan data komplain, penanganan dan pembuatan laporan. DFD level 0 Pengelolahan Data Komplain dapat dilihat pada gambar 3 .

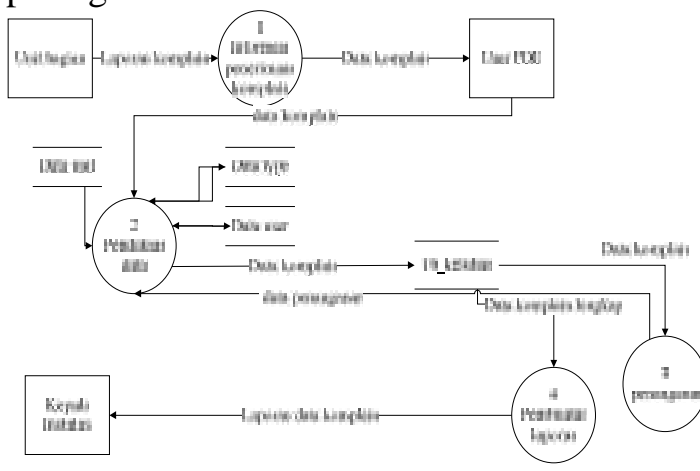

Gambar 3. DFD Level 0 Aplikasi Pengelolahan Data Komplain

DFD Level 1 merupakan gambaran lebih rinci dari diagram konteks pada sistem. BerdasarkanDFD Level 0 terdapat penjabaran DFD Level 1 informasi penerimaan komplain, di mana DFD ini mempunyai proses. penjabaran proses pada sistem ini yaitu informasi penerimaan komplain, pada DFD Level 1 informasi penerimaan complain gambar 4 mempunyai 2 entity pemberian informasi yaitu Unit Bagian dan User PDE. 


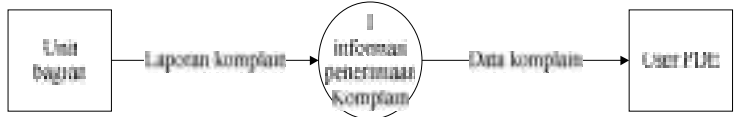

Gambar 4. DFD Level 1 Penerimaan

Komplain Aplikasi Pengelolahan Data Komplain

Berdasarkan DFD Level 0 terdapat penjabaran DFD Level 1 pencatatan data komplain, di mana DFD ini mempunyai 4 proses. Penjabaran proses pada sistem ini yaitu pencatatan data user, pencatatan data type, pencatatan data unit, pencatatan data komplain. Pada DFD Level 1 pencatatan data pada gambar 5 mempunyai1 entity yang memberikan informasi pada system yaitu User PDE.

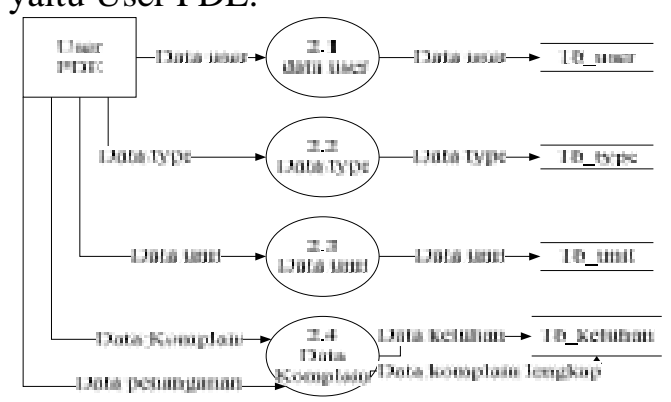

Gambar 5. DFD Level 1 Pencatatan

Aplikasi Pengelolahan Data Komplain

Berdasarkan DFD Level 0 terdapat penjabaran DFD Level 1 penanganan komplain, di mana DFD ini mempunyai 2 proses yaitu pengecekan masalah dan penyelesaian penanganan. Di mana DFD Level 1 penanganan complain pada gambar 6 mempunyai 1 entity yaitu User PDE.

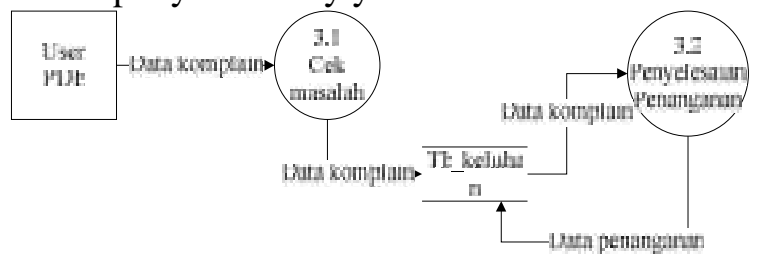

Gambar 6. DFD Level 1 Penanganan Komplain

Berdasarkan DFD Level 0 terdapat penjabaran DFD Level 1 pembuatan laporan, di mana DFD ini mempunyai 1 proses. Pada DFD Level 1 pembuatan laporan pada gambar 7 mempunyai 2 entity yaitu User PDE dan Kepala Instalasi.

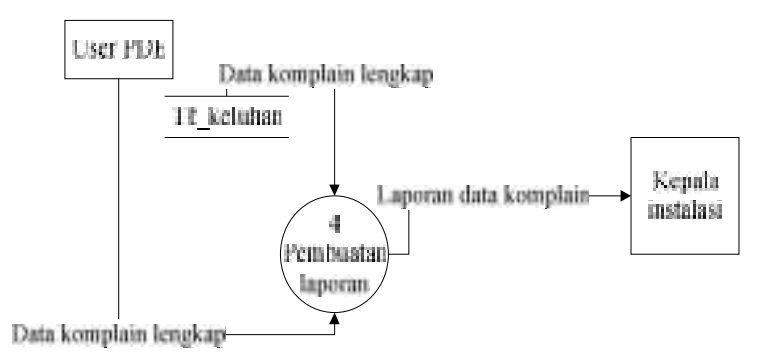

Gambar 7. DFD Level 1 Pembuatan

Laporan Aplikasi Pengelolahan Data Komplain

\section{HASIL DAN PEMBAHASAN}

Sistem Pendukung Keputusan ini dibuat oleh penulis menggunakan bahasa pemrograman PHP dan Database MySQL. Penulis menggunakan bahasa ini karena mudah dipahami dalam pembuatan sistem dan juga dapat digabungkan dengan bahasa pemrograman HTML yang mendukung penggunaan program ini.

Aplikasi ini dijalankan secara intranet, karena digunakan secara internal untuk proses penilaian komplain. Pada aplikasi ini admin sebagai pengentry data, diantaranya memasukkan data komplain dan kriteria, sedangkan admin unit yang mengelola penentuan kriteria kinerja unit.

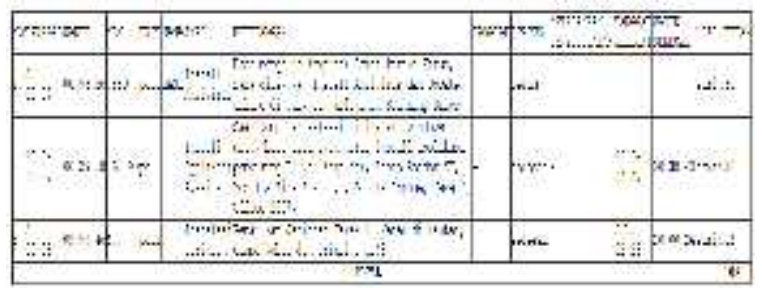

Gambar 8. Contoh Laporan dari Hasil Sistem

\section{KESIMPULAN}

Dari hasil pembahasan mengenai perancangan dan pembuatan Sistem Aplikasi Pengelolahan Data Komplain Untuk Mengukur Kualitas Kinerja Unit PDE Berbasis Web Di Rsud Bangil, di dapat beberapa kesimpulan, diantaranya: Aplikasi yang dibuat dapat menerima dan mengarsipkan data komplain seperti yang dikehendaki oleh user. Aplikasi yang dibuat dapat menghasilkan data komplain berdasarkan periode waktu yang ditentukan. Dengan adanya aplikasi ini, dapat lebih 
muda menangani berbagai komplain yang ada.

\section{REFERENSI}

[1] Al-Bahra bin Ladjamudin. 2005. Analisis dan Desain Sistem Informasi.Yogyakarta: GrahaIlmu.

[2] Rizky Dhanta. 2009. Pengantar Ilmu Komputer. Surabaya: INDAH.

[3] Romeo. 2003. Testing dan Implementasi Sistem Edisi Pertama. Surabaya: STIKOM

[4] Whitten, Jeffery L; Lonnie D Bentley; dan Kevin C Dittman. 2004. Metode Desain \& Analisis Sistem edisi 6. Yogyakarta: Andi
[5] Rsud.pasuruankab, 2013. Gambaran umum. Diperoleh 11 Februari 2012, dari http://rsud.pasuruankab.go.id/

[6] Madcoms, 2009. Menguasai XHTML, CSS, PHP, \& MySQL melalui DREAMWEAVER. Yogyakarta: Penerbit Andi.

[7] Nugroho, Bunafit, Database Relasional dengan MySQL, Andi Yogyakarta, Yogyakarta, 2004.

[8] Syaifullah, 2010, Pengenalan Metode AHP (Analytical Hierarchy Process)

[9] Kusirini, M.Kom, 2012, Konsep dan Aplikasi Sistem Pendukung Keputusan. STMIK AMIKOM Yogyakarta.

[10] Jogiyanto, HM. Analisis dan Desain Sistem Informasi, Yogyakarta,ANDI Yogyakarta 2005 